Proc. Indian Acad. Sci. (Earth Planet. Sci.), Vol. 97, No. 2, December 1988, pp. 183-191.

(C) Printed in India.

\title{
Water characteristics and transport of the Antarctic circumpolar current in the Indian Ocean
}

\author{
P M MURALEEDHARAN and BASIL MATHEW* \\ National Institute of Oceanography, Dona Paula 403004, India \\ *Naval Physical and Oceanographic Laboratory, Cochin 682004, India \\ MS received 14 April 1988; revised 22 August 1988
}

\begin{abstract}
Geostrophic velocities are computed across meridians $37^{\circ} \mathrm{E}$ and $105^{\circ} \mathrm{E}$ using hydrographic data. The estimated mass transport is represented on a temperature-salinity diagram. The characteristics of the water within the Antarctic circumpolar current at $37^{\circ} \mathrm{E}$ and $105^{\circ} \mathrm{E}$ are discussed. The computed transport agrees with the previous estimates. Transports due to the current between $45^{\circ} \mathrm{S}$ and the Antarctic continent at these two meridians are comparable. The westerly flow south of $42^{\circ} \mathrm{S}$ at $105^{\circ} \mathrm{E}$ is associated with a cyclonic eddy which appears to be a permanent feature, whereas the one at $50^{\circ} \mathrm{S}$ is related to the topography of the region.
\end{abstract}

Keywords. Antarctic circumpolar current; mass transport; bivariate distribution; Indian Ocean.

\section{Introduction}

The Antarctic circumpolar current (ACC) is the only ocean current circling the entire globe. Although the average speed of this eastward current is much lower (approximately $15 \mathrm{~cm} / \mathrm{s}$ ) than that of the equatorial currents, it transports a large amount of water because of its considerable horizontal and vertical extents. From geostrophic computations and direct current measurements it is well established that the ACC extends down to the bottom of the ocean (Callahan 1971). Attempts have been made in the past to estimate the net transport of the ACC by assuming geostrophic balance (Sverdrup et al 1942; Jacobs and Georgi 1977; Nowlin et al 1977) and by direct measurements. The direct measurements were mostly made in the Drake Passage (Reid and Nowlin 1971; Nowlin et al 1977; Whitworth et al 1982; Whitworth 1983) and along a section south of Australia (Callahan 1971). However, very little effort was made to study the modal properties of the waters carried by the ACC. In the present study, we have tried to find out the geostrophic transport across two sections in the Indian Ocean and represent it in bivariate classes of potential temperature and salinity.

\section{Material and method}

Two hydrographic sections consisting of 26 stations were used for the present study. The western section at $37^{\circ} \mathrm{E}$ was covered by the research vessel Robert $D$ Conrad during its 17 th cruise in March 1974, while the one at $105^{\circ} \mathrm{E}$ was covered in November 1971 by the US vessel Eltanin. The station locations are given in figure 1. The western section at 


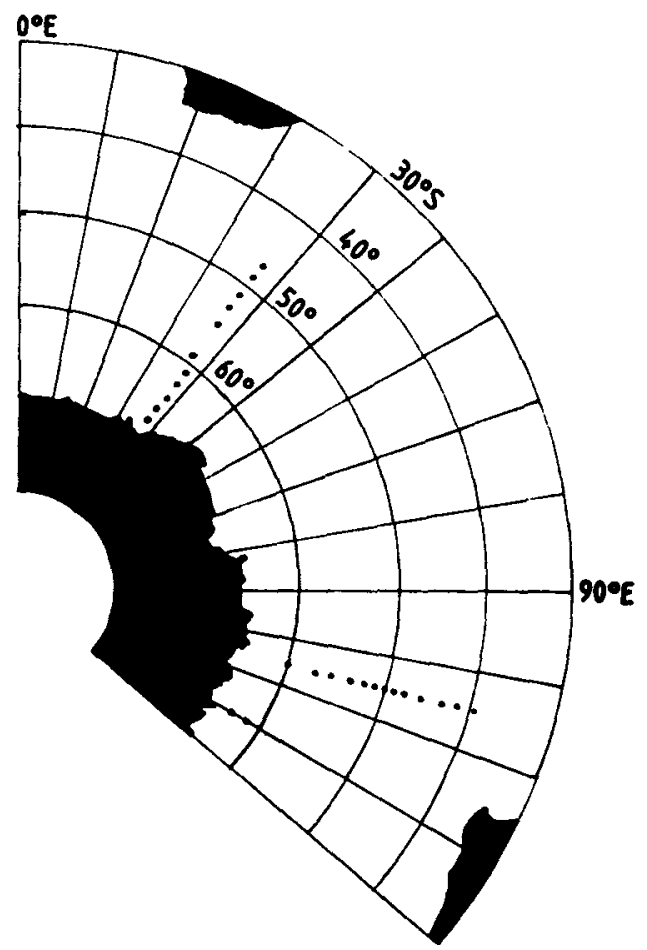

Figure 1. Track chart and station positions.

$37^{\circ} \mathrm{E}$ represents only a part of the ACC. As the section at $105^{\circ} \mathrm{E}$ extends only up to $60^{\circ} \mathrm{S}$, two additional stations to the south of $60^{\circ} \mathrm{S}$ were taken along $120^{\circ} \mathrm{E}$. The latter were covered in the same cruise. It was assumed that this would not cause any appreciable error as the ACC is fairly steady south of the polar front (PF).

The geostrophic velocities were computed between station pairs relative to the deepest common observed depths following Callahan (1971) (figures 2 and 3). Vertical sections of potential temperature, salinity and geostrophic velocity were used for computing the transport and representing it in bivariate classes of potential temperature and salinity. In order to get the minute details, classes of potential temperature and salinity were chosen with smaller intervals, of $0.5^{\circ} \mathrm{C}$ and $0.1 \%$ respectively. The transports were computed through each solenoid formed by potential temperature and station pairs and integrated to get the total transport. This is achieved by superimposing potential temperature and salinity diagrams. The transport (flux) in each solenoid is differentiated again with respect to salinity in order to represent it on a temperature-salinity $(\mathrm{T}-\mathrm{S})$ diagram.

Figures 4 and 5 represent the net transport in bivariate classes of potential temperature $\left(0.5^{\circ} \mathrm{C}\right.$ intervals) and salinity $(0.1 \%$ intervals). This method has the added advantage of giving the properties of the waters carried by the current and their contribution to the net flux.

To facilitate easy comparison, the geographical boundaries are chosen in such a way that the domains west of $50^{\circ} \mathrm{E}$ and east of $90^{\circ} \mathrm{E}$ represent, respectively, the western and eastern regions of the Indian Ocean sector of the Southern Ocean. 


\section{Results and discussion}

\subsection{The current structure}

Vertical sections of geostrophic currents across the two sections $\left(37^{\circ} \mathrm{E}\right.$ and $\left.105^{\circ} \mathrm{E}\right)$ are shown in figures 2 and 3 . The velocity structure across $37^{\circ} \mathrm{E}$ (figure 2 ) shows a weak zonal eastward component between $55^{\circ} \mathrm{S}$ and $60^{\circ} \mathrm{S}$ in the upper $1500 \mathrm{~m}$. Beyond $60^{\circ} \mathrm{S}$ it goes on decreasing, and the flow becomes westward south of $67^{\circ} \mathrm{S}$. The eastward flow is separated into two distinct zones: a narrow high-velocity core $(>15 \mathrm{~cm} / \mathrm{s})$ just south of the India-Antarctica Ridge and the less intense belt further south (near $57^{\circ} \mathrm{S}$ ) already mentioned. At the surface, the polar front is located north of $50^{\circ} \mathrm{S}$. Lutjeharms (1985) observed that the polar front was around $50^{\circ} \mathrm{S}$ in the western Indian Ocean. Here the maximum velocity exceeds $15 \mathrm{~cm} / \mathrm{s}$. The westward flow is confined to the extreme southern boundary of the section. This suggests a narrow and weak contribution from

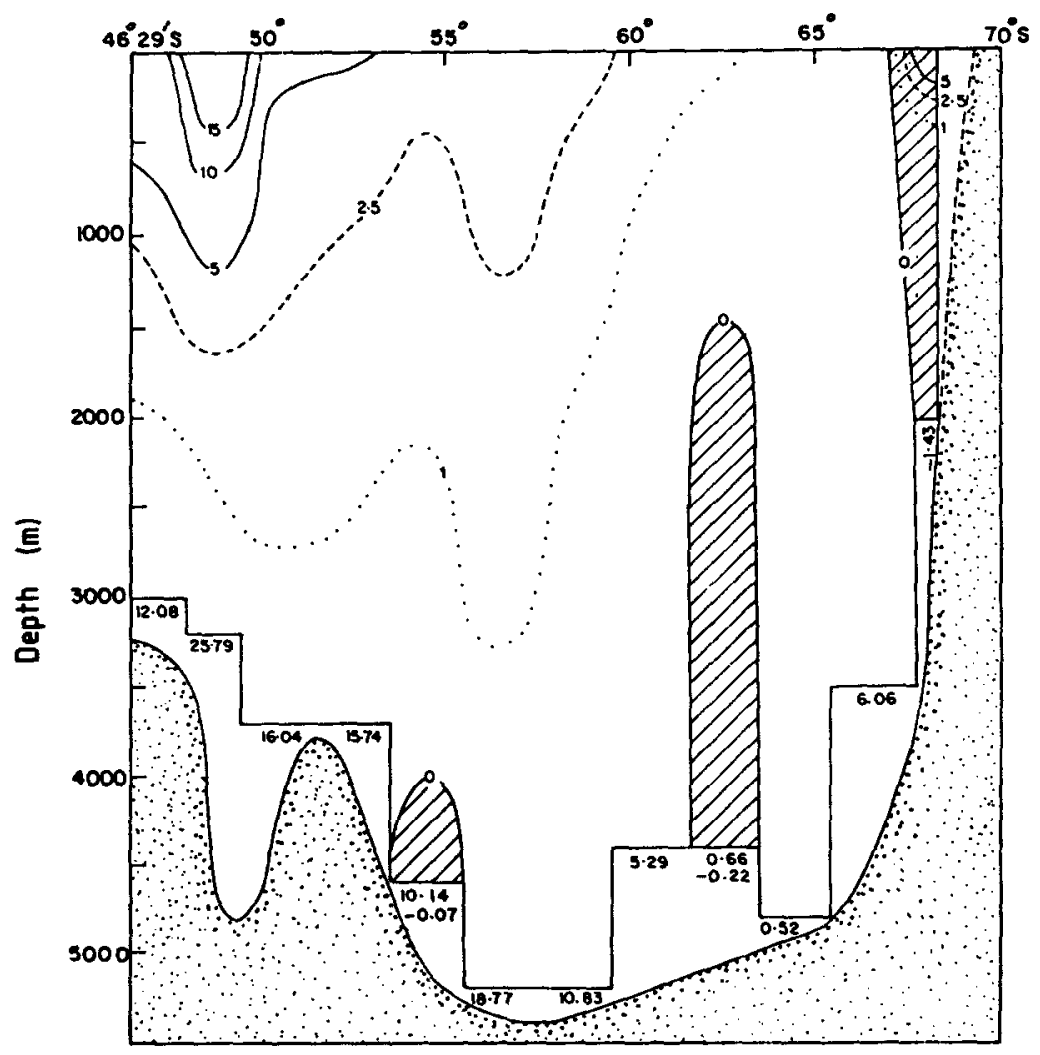

Figure 2. Geostrophic flow and transport across $37^{\circ} \mathrm{E}$ relative to the greatest common observed depths. Straight horizontal lines show the greatest common observed depth for station pairs. Westward flows are hatched and velocity contours are shown by solid lines for velocities at $5 \mathrm{~cm} / \mathrm{s}$ intervals and dashed/dotted lines for velocites with smaller intervals between them. Quantities of mass transport $\left(10^{6} \mathrm{~m}^{3} \mathrm{~s}^{-1}\right)$ between station pairs are shown below the horizontal lines. Positive and negative values indicate eastward and westward transports respectively. Negative transports, being insignificant, are not counted in the $50 \%$ and $75 \%$ boundaries. 


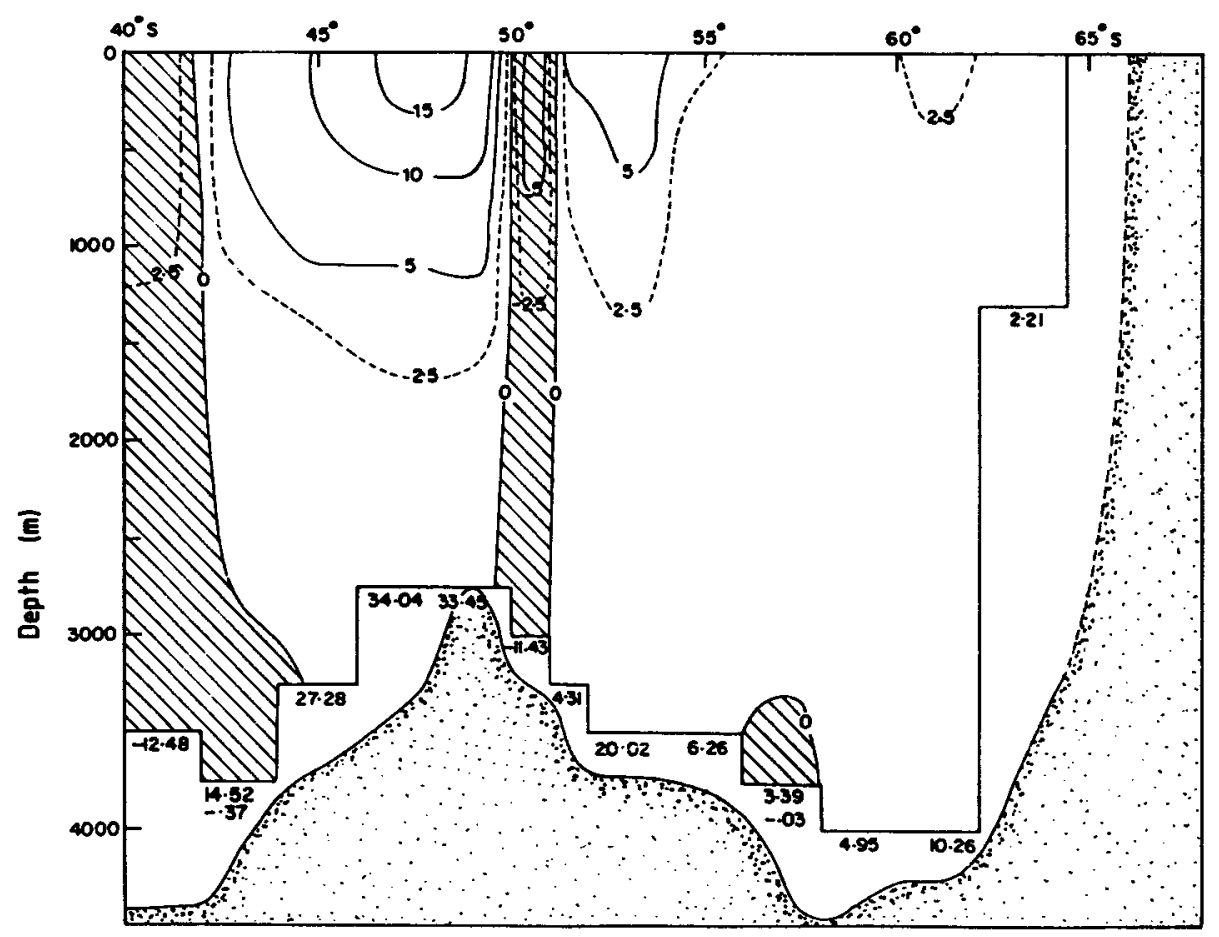

Figure 3. Geostrophic flow and transport across $105^{\circ} \mathrm{E}$ relative to the greatest common observed depths. See legend to figure 2 for details.

the east wind drift in this region. The zone of the Antarctic front is thus situated roughly around $67^{\circ} \mathrm{S}$, slightly south of the position observed by Lutjeharms (1985).

A sub-Antarctic front (SAF) and a polar front are observed in the eastern section (figure 3). A westward flow, which separates these two fronts, extends down to the crest of the India-Antarctica Ridge. Callahan (1971) also found the same feature. He suggested that the zone over the ridge was characterized by extremely weak vertical shear throughout the water column. This could result in a westward flow or vanishing of the zonal component. The dynamics behind the westward countercurrent embedded in the ACC exactly over the India-Antarctica Ridge are still unknown. Callahan (1971) believed that the ACC was affected by major topographic features. According to him the position of the countercurrent is an indication of the influence of topography on the upper westward flow. He also felt, however, that the part played by the wind stress distribution could not be ignored. Interestingly, the zone of maximum westerly winds in the southern ocean $\left(50^{\circ} \mathrm{S}\right)$ exactly coincides with the latitude of the countercurrent (Von Arx 1957). This strengthens the case for a topographic influence on the westward flow. Quoting Sverdrup et al (1942), Callahan (1971) pointed out that large-scale meanders in the ACC have been observed repeatedly over the meridional ridge system. This can be explained qualitatively by the conservation of potential vorticity (Pond and Pickard 1983), but a more complete dynamical model will help one to understand the real cause of this westward flow.

The westward flow at $40^{\circ} \mathrm{S}$ (figure 3 ) could be associated with a cyclonic eddy. Its 
presence has been confirmed between Antarctica and the region south of Australia by Sarchenko et al (1978). A similar cyclonic circulation was noticed in the vicinity of the polar front at the Drake Passage by Joyce and Patterson (1977). Wyrtki (1962) observed a cyclonic circulation between $105^{\circ} \mathrm{E}$ and $110^{\circ} \mathrm{E}$, centred at $35^{\circ} \mathrm{S}$ all along the depths that were investigated. This appears to be a permanent feature.

Thus, the net eastward flux of the ACC is mostly derived from the sub-Antarctic zone (SAZ) and the polar frontal zone (PFZ). The contribution of SAZ is the more dominant of the two. The core velocities of these two zones are 15 and $5 \mathrm{~cm} / \mathrm{s}$ respectively. A less intense belt is also seen around $61^{\circ} \mathrm{S}$, which could be either an extension of the PFZ or the Antarctic zone (AZ).

From the data collected during the Melville, Yelcho and Atlantis II cruises Whitworth et al (1982) calculated the maximum velocity of the ACC in both SAF and $P F$ and the values exceed $40 \mathrm{~cm} / \mathrm{s}$. However, such high velocities could not be seen along $132^{\circ} \mathrm{E}$, at $115^{\circ} \mathrm{E}$ (Callahan 1971), or along $145^{\circ} \mathrm{E}$ (Sverdrup 1940), where the velocities were less than half the values reported by Whitworth et al (1982). In the present study, the velocity of the ACC never exceeded $20 \mathrm{~cm} / \mathrm{s}$. The high velocity at the Drake Passage was mainly due to the narrowness of the path of the ACC.

\subsection{Transport}

The zonal transports computed within the $\mathrm{ACC}$ across $37^{\circ} \mathrm{E}$ and $105^{\circ} \mathrm{E}$ amount to $122 \times 10^{6} \mathrm{~m}^{3} \mathrm{~s}^{-1}$ and $160 \times 10^{6} \mathrm{~m}^{3} \mathrm{~s}^{-1}$ respectively. The excess transport at $105^{\circ} \mathrm{E}$ may be attributed to the greater meridional coverage of this section compared to that at $37^{\circ} \mathrm{E}$; otherwise, both the values are comparable. The westward flux is more conspicuous in the eastern section, while it is almost absent to the west.

The previous measurements of transport within the ACC in all the three sectors of the southern ocean correlate well with the present estimates. Nowlin et al (1977) computed a transport of $124 \times 10^{6} \mathrm{~m}^{3} \mathrm{~s}^{-1}$ across the Drake Passage and his estimate is comparable with that of Whitworth (1983), who estimated an average transport of $121 \times 10^{6} \mathrm{~m}^{3} \mathrm{~s}^{-1}$ from a 370-day current record. Bryden and Pillsbury's (1977) estimate of $262 \times 10^{6} \mathrm{~m}^{3} \mathrm{~s}^{-1}$ at the Drake Passage (based on one year's records from $6 \mathrm{~m}$ ) deviates considerably from the normal value and the extremes, according to Nowlin et al (1977), might have been the result of a longer observation period.

The present estimates of $122 \times 10^{6} \mathrm{~m}^{3} \mathrm{~s}^{-1}$ at $37^{\circ} \mathrm{E}$ and $160 \times 10^{6} \mathrm{~m}^{3} \mathrm{~s}^{-1}$ at $105^{\circ} \mathrm{E}$ are supported by the values of Jacobs and Georgi (1977) and Callahan (1971). Jacobs and Georgi have calculated the transport between Cape Agulhas and Antarctica and these values slightly exceed the present ones, while Callahan's estimates at $115^{\circ} \mathrm{E}$ and $132^{\circ} \mathrm{E}$ are $149 \times 10^{6} \mathrm{~m}^{3} \mathrm{~s}^{-1}$ and $156 \times 10^{6} \mathrm{~m}^{3} \mathrm{~s}^{-1}$ respectively.

\subsection{Bivariate distribution of the flux}

The distribution of the total transport among classes of potential temperature $\left(0.5^{\circ} \mathrm{C}\right.$ intervals) and salinity (0.1\% intervals) is shown in figures 4 and 5 . The transport values enclosed by the solid lines are of those classes that together contribute $50 \%$ of the total transport and are said to be within the $50 \%$ boundary. Similarly the $75 \%$ boundary (dashed lines) is defined as that which encloses transport values of classes that contribute $75 \%$ of the total transport. The following are the numbers of classes enclosed by the $50 \%$ and $75 \%$ boundaries in the western and eastern regions. 


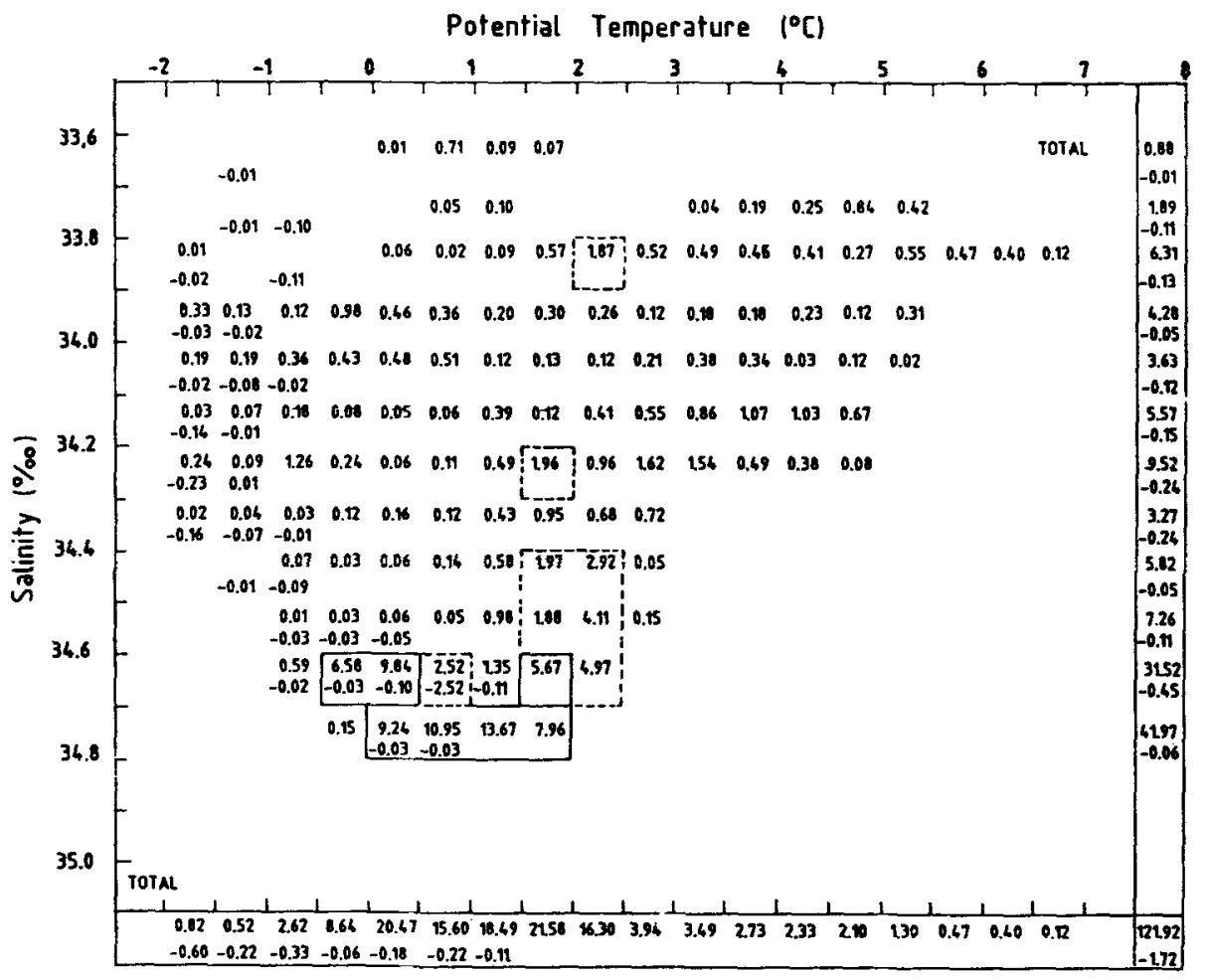

Figure 4. Distribution of the total transport across $37^{\circ} \mathrm{E}$ in bivariate classes of potential temperature and salinity. The solid-line boundary encloses classes that together contribute $50 \%$ of the total transport; the dashed-line boundary encloses classes that contribute $75 \%$. The totals at bottom give distribution by potential temperature and those at right distributions by salinity. The total in the box in the bottom right-hand corner gives total transport $\left(10^{6} \mathrm{~m}^{3} \mathrm{~s}^{-1}\right)$ across $37^{\circ} \mathrm{E}$. Negative values indicate westward transport.

$\begin{array}{lcl}\text { Region } & 50 \% & 75 \% \\ \text { Western (figure 4) } & 7 & 15 \\ \text { Eastern (figure 5) } & 12 & 31\end{array}$

The two regions can be compared with regard to the number of classes enclosed by the $50 \%$ and $75 \%$ boundaries. Both $50 \%$ and $75 \%$ boundaries reveal that the eastern region of the southern Indian Ocean is more heterogeneous than the western region. Along $105^{\circ} \mathrm{E}$ the primary, secondary and tertiary modes are very prominent, both at the $50 \%$ and $75 \%$ levels, and are widely scattered throughout the water column (figure 5). At $37^{\circ} \mathrm{E}, 75 \%$ of the circumpolar current has a salinity $>34.2 \%$ and a potential temperature ranging from $-0.5^{\circ} \mathrm{C}$ to $2.5^{\circ} \mathrm{C}$. The highly saline primary mode within the $50 \%$ boundary has only 7 classes while the additional $25 \%$ includes 8 classes, probably because of the admixture of water mass from the north (figure 4). Similar mixing of water masses is also inferred at the eastern region from the additional 19 classes within the $75 \%$ boundary. It is also presumed that the water in this region is comparatively stratified.

The less saline $\left(<34.3 \%\right.$ ) warm water $\left(3-7^{\circ} \mathrm{C}\right)$ noticed in the $\mathrm{ACC}$ at $37^{\circ} \mathrm{E}$ (figure 4) can be attributed to the southward advection of the Agulhas current. This accounts for 


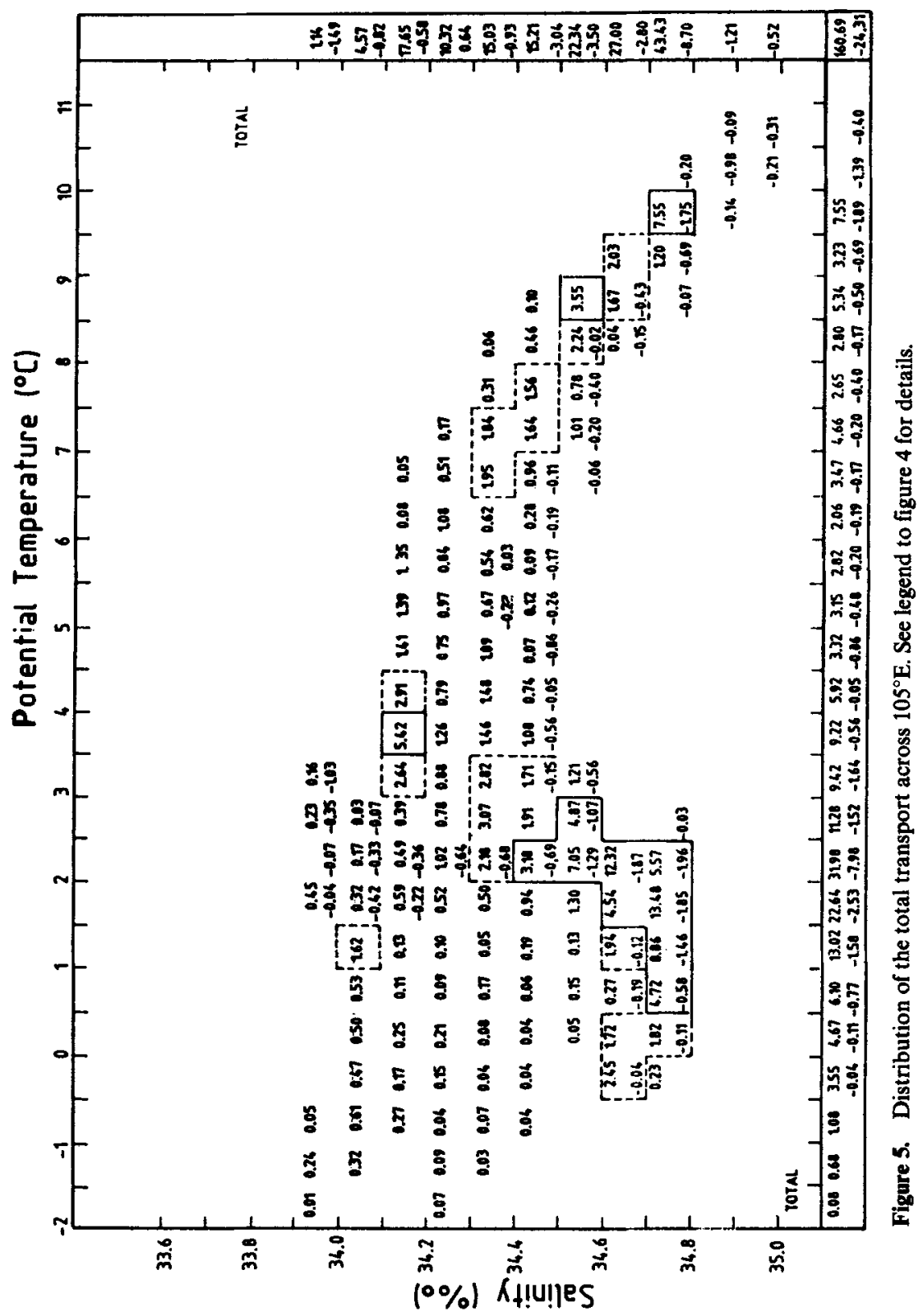


about $10 \%$ of the total volume transport in the ACC. Grundlingh (1978), using a satellite-tracking device, observed a southerly flow in the Agulhas current around $37^{\circ} \mathrm{E}$ and thought it to be the recycling of the Agulhas current. He could also locate the rapid eastward return of the Agulhas current west of $20^{\circ} \mathrm{E}$ and its path towards the east along $40^{\circ} \mathrm{S}$. Therefore the warm, less saline water at $37^{\circ} \mathrm{E}$ and $45^{\circ} \mathrm{S}$ in the present section must be due to the influence of the Agulhas current. Similarly, the presence of saline water within the potential temperature range $7-11^{\circ} \mathrm{C}$ at $105^{\circ} \mathrm{E}$ (figure 5) is a clear evidence of the northward-flowing West Australian current. The secondary mode within the $50 \%$ level occupies this part of the current. There is an indication of this northward current in the figures of Hamon (1965) for the period October 16 to November 15 1960. An analogous current structure was observed by Wyrtki(1957) and Rochford (1969) at the extreme west and east of the Indian Ocean sector of the Southern Ocean during the Austral summer.

\section{Conclusions}

In the present study the velocity of the ACC never exceeded $20 \mathrm{~cm} / \mathrm{s}$. Two westward flows were noticed at $50^{\circ} \mathrm{S}$ and $40^{\circ} \mathrm{S}$ across the meridian $105^{\circ} \mathrm{E}$. The westward flow at $40^{\circ} \mathrm{S}$ was found to be associated with a cyclonic eddy. The computed geostrophic transport across $37^{\circ} \mathrm{E}$ and $105^{\circ} \mathrm{E}$ amounts to $122 \times 10^{6} \mathrm{~m}^{3} \mathrm{~s}^{-1}$ and $160 \times 10^{6} \mathrm{~m}^{3} \mathrm{~s}^{-1}$ respectively. The distribution of the total transport in bivariate classes of potential temperature and salinity indicates that the eastern region of the Southern Ocean is more heterogeneous than the western region. The influence of a less saline Agulhas current and a saline West Australian current may be inferred from the frequency distribution.

\section{References}

Bryden H L and Pillsbury R D 1977 Variability of deep flow in the Drake Passage from year-long current measurements; J. Phys. Oceanogr. 7 803-810

Callahan J E 1971 Velocity structure and flux of the Antarctic circumpolar current south of Australia; J. Geophys. Res. 76 5859-5864

Grundlingh M L 1978 Drift of a satellite-tracked buoy in the southern Agulhas current and Agulhas return current; Deep Sea Res. 25 1209-1224

Hamon B V 1965 Geostrophic current in the southeastern Indian Ocean; Aust. J. Mar. Freshwater Res. 16 255-271

Jacobs S S and Georgi D T 1977 Observations on the southwest Indian/Antarctic Ocean. In A voyage of discovery (ed.) M. Angel (Oxford: Pergamon Press) pp. 43-84

Joyce T M and Patterson S L 1977 Cyclonic ring formation at the polar front in the Drake Passage; Nature (London) 265 181-233

Lutjeharms J R E 1985 Location of frontal systems between Africa and Antarctica: some preliminary results; Deep Sea Res. 32 1499-1509

Nowlin W D, Whitworth T III and Pillsbury R D 1977 Structure and transport of the Antarctic circumpolar current at Drake Passage from short-term measurements; J. Phys. Oceanogr. 7 768-802

Pond S and Pickard G 1983 Introductory dynamical oceanography (Oxford: Pergamon Press) p. 329

Reid J L and Nowlin Jr W D 1971 Transport of water through the Drake Passage; Deep Sea Res. 18 51-64

Rochford D J 1969 Seasonal variations in the Indian Ocean along $110^{\circ} \mathrm{E}$. 1. Hydrological structure of the upper $500 \mathrm{~m}$; Aust. J. Mar. Freshwater Res. 13 1-17

Sarchenko V G, Emery W J and Vladimirov D A 1978 A cyclonic eddy in the Antarctic circumpolar 
current south of Australia. Results of Soviet-American observations aboard RV Professor Zubov; $J$. Phys. Oceanogr. 8 825-837

Sverdrup H O 1940 British, Australian, New Zealand Antarctic research expedition: Hydrology discussion; BANZARE Report Ser. A, Vol. 3, part 2, sect. 2

Sverdrup H U, Johnson M W and Fleming R H 1942 The oceans (Englewood Cliffs NJ, USA: Prentice-Hall) pp. 1087

Von Arx W 1957 An experimental approach to problems in physical oceanography. In Physics and chemistry of the earth (eds) L H Ahrens, F Press, $K$ Rankama and S K Runcorn (New York: Pergamon Press) Vol. 2, p. 1

Whitworth T III 1983 Monitoring the transport of the Antarctic circumpolar current at Drake passage; J. Phys. Oceanogr. 13 2045-2057

Whitworth T III, Nowlin Jr W D and Worly S J 1982 The net transport of the Antarctic circumpolar current through Drake Passage; J. Phys. Oceanogr. 12 960-971

Wyrtki K 1957 Die zirkulation an der oberfläche der südostasiatischen gewässer; Dt. Hydrog. Z. 10 1-13

Wyrtki K 1962 Geopotential topographies and associated circulation in the southeastern Indian Ocean; Aust. J. Mar. Freshwater Res. 13 1-17 